\title{
A rapid non-destructive DNA extraction method for insects and other arthropods.
}

Mark A. Castalanelli ${ }^{1,2,3^{*}}$, Dustin L. Severtson ${ }^{3}$, Cameron J. Brumley ${ }^{1,3}$, Andras

Szito $^{1,3}$, Robert G. Foottit ${ }^{4}$, Mike Grimm ${ }^{1,3}$, Kylie Munyard ${ }^{2}$, David M. Groth ${ }^{2}$

Cooperative Research Centre for National Plant Biosecurity, Bruce, ACT, Australia ${ }^{1}$

Curtin Health Innovation Research Institute, Western Australian Biomedical Research Institute, Curtin University of Technology, Perth, Australia ${ }^{2}$

Division of Biosecurity and Research, Department of Agriculture and Food Western Australia, WA, 6151, Australia $^{3}$

National Environmental Health Program - Invertebrate Biodiversity, Agriculture and Agri-Food Canada, Ottawa, Ontario, Canada ${ }^{4}$

\section{Corresponding Author}

Mark Castalanelli

mark.castalanelli@agric.wa.gov.au

3 Baron-Hay Crt, South Perth, 6151, Australia

ph: +61 893683754

fax: +61 894742405

\section{Co-Authors}

Dustin L. Severtson, 3 Baron-Hay Crt, South Perth, 6151, Australia

Cameron J. Brumley, 3 Baron-Hay Crt, South Perth, 6151, Australia

Andras Szito, 3 Baron-Hay Crt, South Perth, 6151, Australia

Robert G. Foottit, Agriculture and Agri-Food Canada/Agriculture et Agroalimentaire

Canada, Research Centre, K. W. Neatby Building, 960 Carling Avenue, Ottawa,

Ontario, K1A 0C6 CANADA 
Mike Grimm, 3 Baron-Hay Crt, South Perth, 6151, Australia

Kylie Munyard, Biomedical Science, Curtin University, Kent St, 6012, Australia

David M. Groth, Biomedical Science, Curtin University, Kent St, 6012, Australia

\section{Keywords}

Non-destructive, insect, DNA, extraction, arthropod, rapid, taxonomy

Word count for the abstract: 99

Word count for the body: 2400 


\begin{abstract}
Preparation of arthropods for morphological identification often damages or destroys DNA within the specimen. Conversely, DNA extraction methods often destroy the external physical characteristics essential for morphological identification. We have developed a rapid, simple and non-destructive DNA extraction technique for arthropod specimens. This technique was tested on four arthropod orders, using specimens that were fresh, preserved by air drying, stored in ethanol, or collected with sticky or propylene glycol traps. The technique could be completed in twenty minutes for Coleoptera, Diptera and Hemiptera, and two minutes for the subclass Acarina, without significant distortion, discolouration, or other damage to the specimens.
\end{abstract}

\title{
Introduction
}

With increased international trade, the interception of economically important arthropod pests by quarantine organisations is becoming more frequent and the establishment of pest species in a non-native environment can be of considerable cost to primary industries (Mack, Simberloff et al. 2000). For example, introduction of the Khapra beetle (Trogoderma granarium Everts) into Australia could cause losses approaching AU\$2 billion (Cook 2003; Armstrong and Ball 2005). Equally importantly, the loss of natural biodiversity caused by newly introduced species displacing the indigenous species can be catastrophic. The identification of arthropod pests typically uses morphological characteristics and is sometimes problematic, potentially failing to recognise a serious pest or to cause alarm over a non-threatening species (Hebert, Cywinska et al. 2003). Difficulties with identification may result from natural phenotypic variation within a species, the involvement of 
morphologically cryptic taxa, limitations of morphological keys, the need to identify partial specimens that lack important taxonomic characteristics, and the shortage of experienced taxonomists required for identification (Hebert, Cywinska et al. 2003). A combination of morphological identification and DNA barcoding is being developed to overcome such problems (Moritz and Cicero 2004; Floyd, Wilson et al. 2009).

Methods used to prepare arthropod samples for morphological identification often prevent the analysis of DNA from the specimen, while the column-based DNA extraction methods most frequently used on arthropods require maceration of the sample, destroying the morphological characteristics required for identification. For this reason, DNA extraction that may cause damage or loss of specimens cannot be performed on Type specimens held in insect collections. Several non-destructive DNA extraction methods have been published, which allow the specimen to be identified using DNA analysis without any obvious alterations to the morphological characteristics (Favret 2005; Pons 2006; Gilbert, Moore et al. 2007; Rowley, Coddington et al. 2007; Hunter, Goodall et al. 2008). However, these methods require the use of toxic or corrosive chemicals (eg. phenol, chloroform, guanidine isothiocyanate), are time-consuming through the need for overnight incubation, or risk the loss of DNA through ethanol or isopropanol precipitation. In addition, some methods are expensive and/or inefficient (Favret 2005; Pons 2006; Gilbert, Moore et al. 2007; Rowley, Coddington et al. 2007; Hunter, Goodall et al. 2008). Because of the varying suitability of the different methods, a laboratory dealing with multiple arthropod taxa may need to establish and validate several methods. 
To validate a single, broadly applicable method, we have used ANDE (www.ande.com.au), a high speed DNA extraction method. The method is based on alkaline hydrolysis of proteins and uses ingredients similar to those already routinely used by morphological taxonomists in the preparation of insect and mite samples for dissection and/or slide mounting (Szito 2007). It is a simpler and quicker method than most other non-destructive DNA extraction techniques.. Extraction of DNA with ANDE was tested on specimens from four arthropod orders, which had been preserved under various conditions. We examined important morphological characteristics before and after DNA extraction. In addition, the method was tested on museum specimens, which had been stored for periods greater than 30 years.

\section{Methods}

Samples were collected and stored as shown in Table 1. Whole specimens from the insect Orders Coleoptera (Dermestidae, Buprestidae and Cerambycidae families), Hemiptera (Aphididae), Diptera (Tephritidae), and the arachnid Order Prostigmata (Eryophyidae) were placed into $0.2-\mathrm{ml}$ microcentrifuge tubes and $50 \mu 1$ of ANDE solution 1 was added. For larger specimens the volume of solution 1 was increased to $100 \mu 1$. Larval specimens were pierced with a micro pin, behind the first abdominal segment, and the pin was immersed in $20 \mu \mathrm{l}$ of ANDE solution 1. Eriophyid mites

were immersed in $10 \mu \mathrm{l}$ of ANDE solution 1. Eriophyid mites were incubated at $99^{\circ} \mathrm{C}$ for $2 \mathrm{~min}$. and all other specimens were heated at $99^{\circ} \mathrm{C}$ for $20 \mathrm{~min}$. After incubation, 0.25 volume of ANDE Solution 2 was added to each tube. Solutions 1 and 2 were mixed by gentle pipetting and an aliquot was transferred to a sterile microcentrifuge tube, leaving the specimen in the original tube for further preparative steps or to be restored to their original conditions of storage. DNA concentration was measured 
using a NanoDrop spectrophotometer (Thermo Fisher Scientific Inc), and extracts were diluted to $20 \mathrm{ng} / \mu \mathrm{l}$ using PCR-grade water.

Primer pairs used for DNA amplification targeted single copy nuclear DNA, multiple copy nuclear DNA, or mitochondrial DNA (Table 2). Reaction volume was $10 \mu 1$, including $1 \mu 1$ of ANDE extracted DNA as template, 2.5 pmoles of each primer, 200 $\mu \mathrm{M}$ of each dNTP (Invitrogen), 0.25U of Taq Platinum (Invitrogen) and Taq polymerase reaction buffer (Invitrogen). Annealing temperatures and extension times varied as shown in Table 2. The thermocycle conditions were: $95^{\circ} \mathrm{C}$ for $5 \mathrm{~min} ; 40$ cycles of: $95^{\circ} \mathrm{C}$ denaturation for $30 \mathrm{~s}$, annealing for $30 \mathrm{~s}$, and $72^{\circ} \mathrm{C}$ for extension; with a single final extension period of $72^{\circ} \mathrm{C}$ for $5 \mathrm{~min}$. PCR products were analysed by electrophoresis on $1.5 \%$ agarose gels and visualised by staining with ethidium bromide. Some samples were analysed by PCR using 0.2U of Phusion High-Fidelity DNA polymerase with Phusion HF buffer (Finnzymes) in a volume of $10 \mu$ with $1 \mu 1$ of template, 4 pmoles of each primer, $200 \mu \mathrm{M}$ of each dNTP (Invitrogen),

After DNA extraction, specimens belonging to the families Aphididae and Eryophyidae required additional preparation steps for mounting on glass microscope slides prior to microscopic examination. Clearing and slide mounting of aphid species has been described previously (Favret 2005).

\section{Results}

Amplification products from DNA extracted by the ANDE procedure from Coleoptera, Hemiptera, and Acarina, are shown in Figure 1, together with results for specimens from which DNA was extracted by the Qiagen column-based method 
(DNEasy). Table 1 summarises the preservation and storage details of the specimens examined and the results of amplification of the targeted genes.

The successful amplification of products from 400-550bp demonstrated that the method is readily applied to specimens that have been stored for more than 20 years. Amplification was not achieved for the oldest sample, which was collected in 1950. Individual primer-pairs did not yield amplification products from all specimens tested. However, specimens from all four orders showed amplification with at least one primer pair (Figure 1).

Figure 2 shows aphids and mites that were cleared and slide mounted without ANDE extraction (A1, B1, C1) and with ANDE extraction (A2, B2, C2). Samples treated with ANDE showed no discernable morphological changes. For example, the prodorsal shield pattern (A2.1) and the featherclaw (A2.2) of Aceria. tosichella (Acarina: Eriophyidae) and other Eriophyid mites are important diagnostic features for classification (Whitmoyer, Nault et al. 1972; Halliday and Knihinicki 2004) and figure B2.2 shows that ANDE extraction did not alter the delicate structures. Although ANDE extraction achieved some degree of clearing, this alone was not sufficient for microscopic analysis when slide mounted in the non-clearing medium Euparal. However, Hoyer's medium produced satisfactory clearing for specimens with and without ANDE treatments.

DNA extraction using ANDE showed no detectable effect on the morphological characteristics of Uroleuchon sonchi (Hemiptera: Aphididae), leaving the fine body setae intact. The weak clearing action on the specimens during DNA extraction 
allowed the subsequent $\mathrm{KOH}$ clearing process to be performed in a shorter time than normal and abrogated the need for piercing of the lateral abdominal wall to obtain good results. In Bactrocera spp. (Diptera: Tephritidae), the wing integrity was lost due to shriveling (Data not shown). No damage to any other morphological features was recorded in this genus. For all coleopteran specimens this extraction method showed no detectable loss of scales or setae, or damage to the male genitalia. Conveniently, ANDE provided sufficient clearing of fatty tissue in the genital region to make morphological determination easier. In Coleoptera, the ANDE treatment was observed to soften joints, allowing easier manipulation of the body parts in the identification process and subsequent mounting.

\section{Discussion}

Many previously described methods for DNA extraction from arthropods require the use of multiple steps, toxic or corrosive chemicals, or expensive components (Favret 2005; Pons 2006; Gilbert, Moore et al. 2007; Rowley, Coddington et al. 2007; Hunter, Goodall et al. 2008). In contrast, ANDE extractions are inexpensive, time and labour efficient, and of low toxicity, allowing the extraction of DNA for amplification without damage to the external characteristics. The wing shriveling observed in Bactrocera spp. can be corrected with critical point drying (Brown 1993). Three genomic regions were amplified to evaluate the extraction process, because they represent different copy-numbers per genome. This allowed the effects of differing abundance of target DNA in the genome to be assessed. Perhaps more importantly, amplifying three different targets allowed us to show that a lack of amplification in a particular reaction was due to reaction-specific factors, such as primer mismatch, and was not caused by general inhibition of PCR by residual extraction materials or DNA 
degradation. DNA extracted from a 50 year old, air dried sample was refractory to amplification. This may have resulted from partial depurination of the DNA, which often occurs in older specimens, leading to extensive DNA fragmentation in the alkaline conditions in ANDE (Sherman and Loeb 1977). We concluded that the Finnzymes product, PhusionTaq, was the most suitable enzyme for this PCR application because it successfully amplified DNA from samples that could not be amplified using Roche Fast Start Taq polymerase. Phusion Taq has been shown previously to be less sensitive to residual inhibitors (Yang and André 2007). However, PCR analysis of DNA from the 50 year old sample failed with both polymerases, supporting the conclusion that the sample lacked DNA of suitable quality.

The non-destructive DNA extraction and mounting method developed by Favret (Favret 2005) is time consuming and requires the use of a minuten pin to liberate DNA from the specimen, which could potentially lead to sample cross contamination (Rowley, Coddington et al. 2007). Our results showed that incision or perforation of the insect is not required to extract DNA using ANDE. Rather, as indicated by a previous study (Gilbert, Moore et al. 2007) the extraction buffer liberates DNA from the interior through openings such as the mouth, anus and spiracles. Removing the puncturing step further reduces handling that may damage the exoskeleton or cuticle, which are required for morphological characterisation. Following ANDE extraction of DNA, slide mounting of some of the specimens requires the normal clearing step in $\mathrm{KOH}$. 
The minute, delicate, and soft body of the Eriophyid mites has previously limited our ability to characterise an individual specimen using both morphological and DNA analysis. Previously, in order to extract DNA, individual specimens were destroyed (Carew, Schiffer et al. 2008). In addition, specimens must be cleared and slide mounted before being identified using light microscopy and are thus unable to be used for DNA extraction. Consequently, assumptions must be made about the species under examination before DNA extraction. Full analysis of individual Eriophyid specimens is important because different species can co-exist on the same plant host. Mite specimens required only $2 \mathrm{~min}$ at $99^{\circ} \mathrm{C}$ for release of DNA and showed no visible damage to the cuticle or body structure. In contrast, the previously described non-destructive method to extract DNA from terrestrial arthropods (Rowley, Coddington et al. 2007) required more than 4 hours. Previous studies on the preservation of mites showed that cryoconservation in water was an efficient medium for short term storage (Rey, Dorda et al. 2004). This study confirmed that amplification was successful when mites were preserved in water. However, morphological examination revealed that the specimens became fragmented during the heating process. This was possibly due to the formation of ice crystals during the freezing process which, when rapidly heated, resulted in rupture of the cuticle. As an alternative, we found that short term storage of the mites prior to DNA extraction and mounting, was best achieved by live preservation in zip lock bags filled with host plant material (up to 1 month), or longer term storage in $70 \%-100 \%$ ethanol.

DNA extraction from a single fresh adult coleopteran specimen yielded DNA sufficient for at least 100 PCR analyses, without visual discolouration or loss of setae. Previously reported problems such as flaccid claws, buckled disks or the apical tarsal 
segments becoming droopy after extraction with guanidine isothiocyanate (Rowley, Coddington et al. 2007) were not observed with this method. The ANDE method was found to soften joints, which allowed easier positioning and manipulation of specimens' legs, antennae and elytra prior to resetting.

The extracted DNA was useful only for amplification of targets up to approximately $800 \mathrm{bp}$. Column-based extracts (Qiagen), which require maceration of the sample, allowed amplification of targets $>2,000 \mathrm{bp}$ in preserved specimens and up to 4,000 bp in fresh specimens (Table 1). While Qiagen is quite often used as a non-destructive technique, a search of the literature revealed no evaluation of this method.

Furthermore, the use of Qiagen often requires several hours of incubation and is a relatively expensive extraction method.

The preservation method used did not appear to influence the results, with most coleopteran specimens producing DNA that could be amplified. However, specimens stored in ethanol for more than a decade gave variable results. The preparation of coleopteran specimens for dissection, slide mounting or card mounting, often involves cleaning with Decon 90, limonene, citricide, Dissolv-it or ultrasound (Szito 2007). Electrophoresis of the extracted DNA revealed that these methods, plus storage in ethanol, caused degradation of the DNA. To be usable for analysis, DNA extraction by ANDE or any other process should be performed prior to such preparative steps.

Extraction of DNA from Dipteran specimens, even by soaking in water, caused shriveling and changes to the shape of the wings (Rowley, Coddington et al. 2007) and, unfortunately, ANDE did not provide a viable alternative. While it may not be 
feasible to stop the changes to the shape of the wing, critical point drying can restore wing shape (Brown 1993). Alternatively it may be possible to extract DNA from the bodies of Diptera using ANDE, without immersion of wings. Alternatively, DNA could be obtained from a single leg if the loss of integrity did not pose taxonomic problems. For unique or taxonomically important specimens, the body part removed for DNA extraction could be retained intact with the original specimen. This would be particularly important for a unique specimen or type specimen that had to be used for DNA barcoding. For any taxonomic group it is essential to be able to make taxonomic comparisons using both original and current morphological taxonomic criteria.

When used directly on larval specimens the ANDE process was highly destructive, causing various degrees of structural collapse. The alkaline components in ANDE solubilise lipids, break down adipose tissue and significantly disfigure the larvae. However, we found that by inserting a pin through the ventral abdominal wall and performing ANDE extraction on the material adhering to the pin, sufficient DNA material could be obtained for amplification, without significantly damaging the larval physical characteristics. Thus, we are of the opinion that this method could be applied to other soft cuticle specimens such as Lepidoptera.

By incorporating this DNA extraction method into our diagnostic protocols we were able to clean the specimen, soften joints, clear fats and soft tissue from within the internal cavities, often without the need for piercing, and soften the abdomens for easy removal of the genitalia. This offers a valuable tool for the traditional morphological taxonomist and may bridge the gap between morphological taxonomy and molecular 
taxonomy without the destruction of important type specimens. The increased ease

and rapidity of species identification will facilitate applications such as biomonitoring

for crop pests, identification of invasive species, and monitoring the effects of climate

change on arthropod populations. Rapid, non-destructive DNA isolation will help to

reduce costs, speed up such processes as DNA barcoding, and allow the increased

integration of new technologies in the development of accurate and rapid taxonomic

identification.

\section{References}

Armstrong, K. F. and S. L. Ball (2005). "DNA barcodes for biosecurity: invasive species identification " Phil. Trans. R. Soc. B 360: 1813-1823.

Brown, B. V. (1993). "A further chemical alternative to critical- point-drying for preparing small (or large) flies." Fly Times 11.

Carew, M., M. Schiffer, et al. (2008). Molecular markers indicate that the wheat curl mite Aceria tosichella Keifer may represent a species complex in Australia, Cambridge University Press.

Cook, D. (2003). Prioritising Exotic Pest Threats to Western Australia Plant Industries. D. o. A. W. Australia, Department of Agriculture Western Australia

Favret, C. (2005). "A New Non-Destructive DNA Extraction and Specimen Clearing Technique for Aphids (Hemiptera)." Proc. Enotomol. Soc. Wash. 107(2): 469-470.

Floyd, R. M., J. J. Wilson, et al. (2009). DNA barcodes and insect biodiversity. Insect Biodiversity. Science and Society. R. G. Foottit and P. H. Adler, Wiley-Blackwell: 417-431.

Gilbert, M. T. P., W. Moore, et al. (2007). "DNA Extraction from Dry Museum Beetles without Conferring External Morphological Damage." PloS One 2(3): e272.

Halliday, R. B. and D. K. Knihinicki (2004). "The occurrence of Aceria tulipae (Keifer) and. Aceria tosichella (Keifer) in Australia (Acari: Eriophyidae)." International Journal of Acarology 30(2): 113-118.

Hebert, P. D. N., A. Cywinska, et al. (2003). "Biological identifications through DNA barcodes." Proc. R. Soc. Lond. B 270: 313-321.

Hunter, S. J., T. I. Goodall, et al. (2008). "Nondestructive DNA extraction from blackflies (Diptera: Simuliidae): retaining voucher specimens for DNA barcoding projects " Molecular Ecology Notes 8: 56-61.

Mack, R. N., D. Simberloff, et al. (2000). "Biotic invasions: causes, epidemiology, global consequences, and control." Ecological Applications 10: 689-710.

Moreau, C. S., C. D. Bell, et al. (2006). "Phylogeny of the Ants: Diversification in the Age of Angiosperms." Science 312(5770): 101 - 104.

Moritz, C. and C. Cicero (2004). "DNA Barcoding: Promise and Pitfalls." PLoS Biology 2(10): 15291531.

Pons, J. (2006). "DNA-based identification of preys from non-destructive, total DNA extractions of predators using arthropod universal primers " Molecular Ecology Notes 6: 623-626.

Rey, I., B. A. Dorda, et al. (2004). "Traditional water mite fixatives and their compatibility with later DNA studies." Experimental and Applied Acarology 34: 59-65.

Rowley, D. L., J. A. Coddington, et al. (2007). "Vouchering DNA-barcoded specimens: test of a nondestructive extraction protocol for terrestrial arthropods." Molecular Ecology Notes 7(6): 915-924.

Sherman, C. W. and L. A. Loeb (1977). "Depurination decreases fidelity of DNA synthesis in vitro." Nature 270(537 - 538). 
Simon, C., F. Frati, et al. (1994). "Evolution, Weighting, and Phylogenetic Utility of Mitochondrial Gene Sequences and a Compilation of Conserved Polymerase Chain Reaction Primers." Ann. Ent. Soc. Am 87(6): 651-701.

Szito, A. (2007). Diagnostic Protocols for Regulated Pests Trogoderma granarium. D. o. A. a. Food: 32.

White, T. J., T. Bruns, et al. (1990). Amplification and direct sequencing of fungal ribosomal RNA genes for phylogenetics. PCR Protocols: A Guide to Methods and Applications. M. A. Innis, D. H. Gelfand, J. J. Sninsky and T. J. White. San Diego, Academic Press, Inc.: 315-322.

Whitmoyer, R. E., L. R. Nault, et al. (1972). "Fine Structure of Aceria tulipae (Acarina: Eriophyidae)." Annals of the Entomological Society of America 65(1): 201-215.

Yang, P. and C. André (2007). "Efficient PCR from whole blood using Finnzymes High

Performance PCR solution." Nature Methods Application Notes.

\section{Acknowledgements}

The authors wish to acknowledge the assistance of Dr Keith Gregg in editing the manuscript. Pia Scanlon for the beautiful auto montage photos of Anthrenocerus australis. The authors would like to acknowledge the support the Australian Government's Cooperative Research Centres Program. 


\section{Tables}

Table 1, Samples used for DNA extraction and amplification.

\begin{tabular}{|c|c|c|c|c|c|c|c|c|c|}
\hline No. & Method & Order & Genus & species & Type & Year & Stored & PrimerSet $^{1}$ & $\begin{array}{l}\text { Max } \\
\text { size } \\
(\mathrm{bp})^{2}\end{array}$ \\
\hline 1 & ANDE & Coleoptera & Orphenus & unknown & Adult & 2008 & $\begin{array}{l}20 \% \text { propylene glycol } \\
\text { then ethanol } \\
20 \% \text { propylene glycol }\end{array}$ & 1 & 550 \\
\hline 2 & ANDE & Coleoptera & Anthrenocerus & australis & Adult & 2008 & then ethanol & $1,2,3$ & 550 \\
\hline 3 & ANDE & Coleoptera & Anthrenus & verbasci & Adult & 2008 & Air dried & 1,3 & 550 \\
\hline 4 & ANDE & Coleoptera & Trogoderma & variabile & Adult & 1995 & Air dried & $1,2,3$ & 550 \\
\hline 5 & ANDE & Diptera & Bactrocera & jarvisi & Adult & 2007 & Air dried and mounted & $1,2,3$ & 800 \\
\hline 6 & ANDE & Coleoptera & Attagenus & unknown & Adult & 2006 & Air dried and mounted & $1,2,3$ & 550 \\
\hline 7 & ANDE & Diptera & Bactrocera & jarvisi & Adult & 1997 & Air dried and mounted & $1,2,3$ & 550 \\
\hline 8 & ANDE & Coleoptera & Orphenus & unknown & Adult & 1994 & Air dried and mounted & 2 & 500 \\
\hline 9 & ANDE & Coleoptera & Neoanthrenocerus & unknown & Adult & 1978 & Air dried and mounted & 1 & 550 \\
\hline 10 & ANDE & Coleoptera & Anthrenus & verbasci & Adult & 1950 & Air dried and mounted & - & - \\
\hline 11 & ANDE & Coleoptera & Hylotrupes & bajulus & Larvae & 2009 & Ethanol & 1 & 550 \\
\hline 12 & ANDE & Coleoptera & Hylotrupes & bajulus & Adult & 2008 & Ethanol & 1,4 & 850 \\
\hline 13 & ANDE & Hemiptera & Uroleucon & sonchi & Adult & 2008 & Ethanol & $1,2,7$ & 550 \\
\hline 14 & ANDE & Coleoptera & Anthrenus & verbasci & Adult & 2007 & Ethanol & 1,2 & 550 \\
\hline 15 & Qiagen & Coleoptera & Trogoderma & granarium & Adult & 2007 & Ethanol & $1,2,3,5$ & 2000 \\
\hline 16 & ANDE & Coleoptera & Trogoderma & granarium & Adult & 1993 & Ethanol & 1 & 550 \\
\hline 17 & ANDE & Coleoptera & Trogoderma & granarium & Larvae & 1993 & Ethanol & 1,2 & 550 \\
\hline 18 & ANDE & Coleoptera & Hylotrupes & bajulus & Larvae & 2009 & Ethanol pin & 1 & 550 \\
\hline 19 & ANDE & Coleoptera & Buprestis & novemaculeta & Larvae & 2009 & Ethanol pin & 1 & 550 \\
\hline 20 & Qiagen & Coleoptera & Trogoderma & variabile & Adult & 2009 & Fresh & $1,2,3,6$ & 4000 \\
\hline 21 & ANDE & Prostigmata & Aceria & tosichella & Adult & 2008 & Fresh & 2,7 & 450 \\
\hline 22 & ANDE & Coleoptera & Cryptolestes & unknown & Adult & 2008 & Fresh & $1,2,3$ & 550 \\
\hline 23 & ANDE & Coleoptera & Sitophilus & oryzae & Adult & 2008 & Fresh & $1,2,3$ & 550 \\
\hline 24 & ANDE & Coleoptera & Tribolium & castaneum & Adult & 2008 & Fresh & 1,3 & 550 \\
\hline 25 & ANDE & Coleoptera & Trogoderma & variabile & Adult & 2008 & Sticky Trap & $1,2,3,4$ & 800 \\
\hline
\end{tabular}

${ }^{1}$ Primer sets described in Table 2,

${ }^{2}$ Maximum size as determined by agarose gel electrophoresis against a DNA ladder. 
Table 2. Amplification primers used in this study

\begin{tabular}{|c|c|c|c|c|c|c|c|c|}
\hline $\begin{array}{c}\text { Primer } \\
\text { No. }\end{array}$ & Target Gene & Primer Name & Primer Sequence 5`-3` & $\begin{array}{c}\text { Aneal } \\
\text { Tm }\end{array}$ & $\begin{array}{c}\text { Ext } \\
\text { Time } \\
\text { (s) }\end{array}$ & $\begin{array}{l}\text { Exp } \\
\text { Size } \\
\text { (bp) } \\
\end{array}$ & Type & Reference \\
\hline \multirow{3}{*}{1} & & 18SF1 & TGCTTGTCTCAAAGATTAAG & & & & & \multirow{9}{*}{$\begin{array}{l}\text { This Study } *^{1} \\
\text { (Simon, Frati } \\
\text { et al. 1994) } \\
\text { (Moreau, Bell } \\
\text { et al. 2006) } \\
\text { (White, Brun } \\
\text { et al. 1990) }\end{array}$} \\
\hline & Multiple Nuclear & 18SR1 & GTATCGTTATTTTTCGTCAC & 43.7 & 30 & 550 & Universal & \\
\hline & & C1-J-1751 & GGATCACCTGATATAGCATTYCC & & & & & \\
\hline \multirow[t]{2}{*}{2} & Mitochondrial & $\mathrm{C} 1-\mathrm{N}-2183$ & CAACATTTATTTTGATTTTTTGG & 43.7 & 30 & 500 & Universal & \\
\hline & & Wg578F & ACYTCGCAGCACCARTGGAA & & & & & \\
\hline \multirow[t]{2}{*}{3} & Single Nuclear & Wg1032R & TGCACNGTGAARACYTGCTGGATGCG & 43.7 & 30 & 450 & Specific & \\
\hline & & ITS1 & TCCGTAGGTGAACCTGCGG & & & & & \\
\hline \multirow[t]{2}{*}{4} & Multiple Nuclear & ITS2 & GCTGCGTTCTTCATCGATGC & 50 & 30 & 800 & Universal & \\
\hline & & N4-F-8772 & CAGGAGCCTCTACATGAGCTTT & & & & & \\
\hline \multirow[t]{2}{*}{5} & Mitochondrial & CB-R-10904 & TTTGATCCTGTRTGGTGWAGAA & 50 & 300 & 4000 & Specific & \multirow[t]{2}{*}{$*^{2}$} \\
\hline & & C3-F-5393 & TTCCCAAATTCACCACTTCG & & & & & \\
\hline \multirow[t]{2}{*}{6} & Mitochondrial & N4-R-9004 & TTGGTTCCCTTATTATTTTTGATTG & 50 & 120 & 2000 & Specific & \multirow{3}{*}{$\begin{array}{l}*^{2} \\
\text { (Simon, Frati } \\
\text { et al. 1994) }\end{array}$} \\
\hline & & CB-J-10933 & TATGTACTACCATGAGGACAAATATC & & & & & \\
\hline 7 & Mitochondrial & CB-N-11367 & ATTACACСТCCTAATTTATTAGGAAT & 43.7 & 30 & 500 & Universal & \\
\hline
\end{tabular}

* Note 1 - The primers were designed by aligning multiple $18 \mathrm{~S}$ sequences (accessions numbers AY748111, AY748105, AY748103, EF213875, EF213892, EF362981) and designing primers within conserved regions. 2 - These primers were created from known Trogoderma variabile sequences. 
Figure 1. PCR amplification products from (A) 18S rRNA gene primers (B) mitochondrial DNA primers (C) Wingless gene primers. Samples 1 to 25 correspond to the specimens shown in Table 1. Lane 1: 100 bp ladder. Samples 15 \& 20: DNA extracted using Qiagen DNeasy Animal Tissue Kit.

Figure 2. Effect of ANDE extraction on external morphological characteristics. Panels on the left show the samples that were slide mounted without ANDE treatment (A1 \& B1) or prior to ANDE extraction (C1), on the right, those extracted with ANDE. (A) Eriophyid mite (sample 21), (B) Aphididae (sample 13), (C) Coleoptera (sample 2). A2.1 and A2.2 illustrate the prodorsal shield (PS) pattern and featherclaw that are used to charactertise A. tosichella. A2.2 shows the integrity of the delicate featherclaw after DNA extraction. 